\section{$536.242: 536.25$}

円筒体の表面熱伝達率について(第 3 報)(1)

坪内为雄 ${ }^{(2)}$, 佐藤千之助 ${ }^{(3)}$

前報において，著者らは自然効流による垂直円筒の 上下端面の表面熟伝達摔を測定し, 水平な正方形平板 の場合と比較し著しい差異のあることを示した(4)．本 報告はその続報として，有限円筒を水平にし，その垂 直面をなす端面および端面の影瞕を受ける円筒面の熱 伝達摔を温度境界層法を熱量法を併用して測定したも のである. 從来，水平円筒に関する多くの研究が発表 されているが，いずれも端部の影響のない円筒面また は端部をも一括した全体としての熱伝達率を測定した もので端面や端部の直接的影響には触れて斿らず，実 際上，有限な円筒に対方る熱伝達率の評価は不明確な ものとなっている。本報告はそれらの点を明らかにす るため，局所熱伝详率の分布就よび平均熱伝達率を測 定し，通常の水平四筒や垂直平板の諸結果と比較考察 を行ったものである。

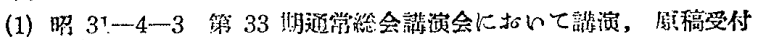

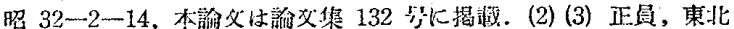

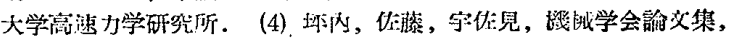
22 卷 116 少, 248 ページ (昭 31).

\subsubsection{8 : 621.43.043.5} 着火油による内燃機関の点火法 ${ }^{(1)}$

長尾不二夫夫 ${ }^{(2)}$ ，小早川 隆 ${ }^{(3)}$ 坂本 昭二(4), 吉井 久士 ${ }^{(5)}$

本文はシリンダ内一発火遲れの短い着火油を少量噴 射し，その自発火により混合気に点火する方法に関し て実験した結果であって，まず CFR 機関を使用し， ガソリンを主燃料とした場合の着火油点火にお汀る着 火油の種類, 喷油量㧍よび吸気温度などが臨界王縮比

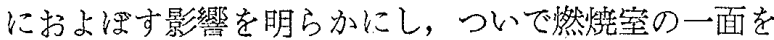
耐熱ガラス張りにした機関を用いて，点火・燃燒の状 態を高速撮影し，燃烓核が各所に生ずることを確かめ た。更に着火油点火によりガりりン機関を運転した結 果，ノックの生じ難いために火花点火の場合よりも圧 繀比を高くすることができ，同時に火花点火では使用 できない希薄混合比でも確実に運転することができ

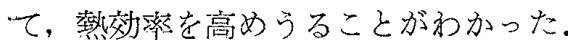

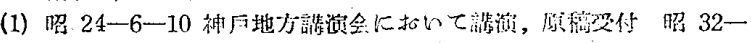

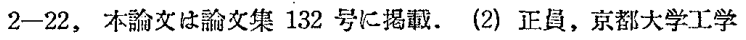
部了. (3) 正員, ダイハツ工然会社 (発表当時京都大学) . (4) (5) 学 生員, 京都大学 (発装当時).

\subsection{6 .3 .018}

\section{予燃焼室式ディーゼル機関の性能向上 ${ }^{(1)}$}

長尾不二夫 ${ }^{(2)}$, 柿本治利 ${ }^{(3)}$, 工藤 弘 ${ }^{(4)}$

予燃焼室式ディーゼル機関の性能注主然㛙室内の燃 焼に左右されることが大きく，これを制御するのに従

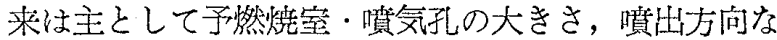
ぞによっていたが，本研究で予燃烇意内の気流および 着火位置が，主燃㜔室内の燃烧に影響することが予想 外に大きいことが明らかにされた。まず模型然燒空に おけるガス䜖出に着火位置が著しい影響を及涩すこと を見出して後，実際の機関において指圧線図からこの 傾向を確認した。予燃焼室上部に高温部を設けてその 付近での着火を促すこと，または流入気流と燃料噴射 の相対位置を利用して予然烓空内の混合気形成の状態 を変えることは，主燃焼窒への燃料噴出うよびそこで の然燒の促進に役立ち，燃烧の等積度を向上させる。

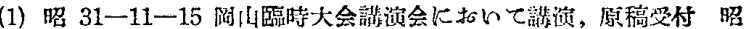

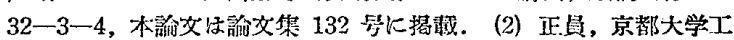
学部. (3) (4) 准員, 京都大学工学缡。

\subsection{4}

\section{Batdorf-Budiansky 両氏のすべり理論 に対する批判(1)}

\section{喜 和 慶 丸(2)}

1949 年にBatdorf および Budiansky 雨氏がすべ り理論と称する新しい望性理論を発表して以来, 該理 論と堌分ひずみ理論のいずれが正しいかが問題とな り，まだ解決されていない，筆者は，この問題に解決 を与えるためには，最も基本的な負荷過程，すなわち 円管の引張りおよびねじり，に対して Batdorf 等の いう特性せん断関数を計算し，比較するのが最も確実 な方法であると考えてそれを行った。その結果はすべ り理論の成立に刘して否定的であり，かつ從来の多く の批判的研究に比較してその決論は決定的のように思 われる。

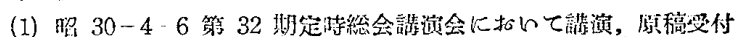

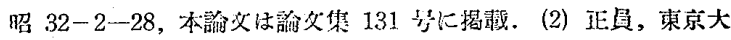
学涩工学研究所。

\title{
雜 誌複写について
}

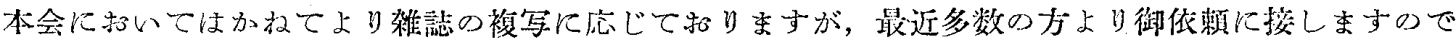

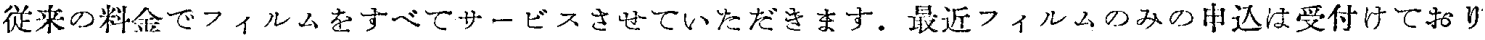

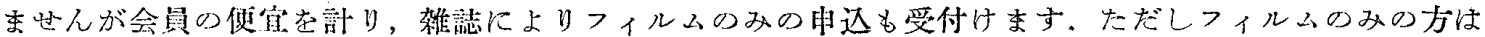
一応和閒合过下さい，複写御希望の方は下記に上り本会あて和中込久下さい。

料金四切 $(200 \mathrm{~mm} \times 300 \mathrm{~mm}) 1$ 枚 $\mathbf{1 0 0}$ 円 $八$ 切 $(150 \mathrm{~mm} \times 200 \mathrm{~mm}) 1$ 枚 $\mathbf{5 0}$ 円 (备フィルム付) キャビネ $(100 \mathrm{~mm} \times 150 \mathrm{~mm}) 1$ 枚 $\mathbf{4 0}$ 円 フィルム $(35 \mathrm{~mm} \times 25 \mathrm{~mm}) \quad 1$ 枚 $\mathbf{2 0}$ 円

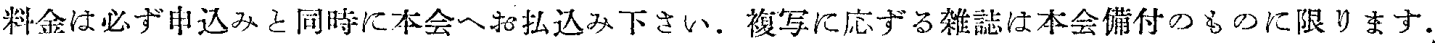

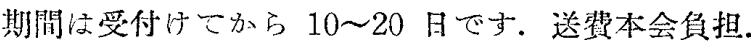

申込方法：下記事項莸御記入の上报込み下さい。
(1) 㫿誌名
(2) 藷者名
(3) 題名 (4) 年次
(5) 巻号数
(6) ページ
（7）大きさ（四切，キャど 亦等）（8）送付先（9）依頼者氏名(ふりがな付）。 